\title{
Identification of Calcium Sulphoaluminate Formation between Alunite and Limestone
}

\author{
Hyung-Seok Kim ${ }^{1}$, Gi-Chun Han ${ }^{2}{ }^{2}$, Ji-Whan Ahn ${ }^{1}$, Kye-Hong Cho ${ }^{1}$, Hee-Chan Cho ${ }^{2}$ \\ ${ }^{1}$ Mineral Resources Research Division, Korea Institute of Geoscience \& Mineral Resources, 30 \\ Gajeong-dong, Yuseong-gu, Daejeon 305-350, Korea; E-Mails: hskim@kigam.re.kr (H.K.); \\ ahnjw@kigam.re.kr (J.A.); khcho99@paran.com (K.C.) \\ 2 Department of Energy Resources Engineering, Seoul National University, 599 Gwanak-ro, \\ Gwanak-gu, Seoul 151-742, Korea; E-Mail: hccho@snu.ac.kr (H.C.) \\ * Author to whom correspondence should be addressed; E-Mail: hhsue@daum.net; Tel.: +42-868-3486; \\ Fax: +42-861-3990
}

Received: 31 May 2009; in revised form: 10 June 2009 / Accepted: 10 June 2009 /

Published: 25 June 2009

\begin{abstract}
This study was carried out to identify the conditions of formation of calcium sulphoaluminate $\left(3 \mathrm{CaO} \cdot 3 \mathrm{Al}_{2} \mathrm{O}_{3} \cdot \mathrm{CaSO}_{4}\right)$ by the sintering of a limestone $\left(\mathrm{CaCO}_{3}\right)$ and alunite $\left[\mathrm{K}_{2} \mathrm{SO}_{4} \cdot \mathrm{Al}_{2}\left(\mathrm{SO}_{4}\right)_{3} \cdot 4 \mathrm{Al}(\mathrm{OH})_{3}\right]$ mixture with the following reagents: $\mathrm{K}_{2} \mathrm{SO}_{4}, \mathrm{CaCO}_{3}, \mathrm{Al}(\mathrm{OH})_{3}$, $\mathrm{CaSO}_{4} \cdot 2 \mathrm{H}_{2} \mathrm{O}$, and $\mathrm{SiO}_{2}$. When $\mathrm{K}_{2} \mathrm{SO}_{4}, \mathrm{CaCO}_{3}, \mathrm{Al}(\mathrm{OH})_{3}, \mathrm{CaSO}_{4} \cdot 2 \mathrm{H}_{2} \mathrm{O}$ were mixed in molar ratios of 1:3:6:3 and sintered at $1,200 \sim 1,300{ }^{\circ} \mathrm{C}$, only $3 \mathrm{CaO} \cdot 3 \mathrm{Al}_{2} \mathrm{O}_{3} \cdot \mathrm{CaSO}_{4}$ and calcium langbeinite $\left(2 \mathrm{CaSO}_{4} \cdot \mathrm{K}_{2} \mathrm{SO}_{4}\right)$ were generated. With an amount of $\mathrm{CaO}$ that is less than the stoichiometric molar ratio, $3 \mathrm{CaO} \cdot 3 \mathrm{Al}_{2} \mathrm{O}_{3} \cdot \mathrm{CaSO}_{4}$ was formed and anhydrite $\left(\mathrm{CaSO}_{4}\right)$ did not react and remained behind. With the amount of $\mathrm{CaSO}_{4}$ that is less than the stoichiometric molar ratio, the amounts of $3 \mathrm{CaO} \cdot 3 \mathrm{Al}_{2} \mathrm{O}_{3} \cdot \mathrm{CaSO}_{4}$ and $2 \mathrm{CaSO}_{4} \cdot \mathrm{K}_{2} \mathrm{SO}_{4}$ decreased, and that of $\mathrm{CaO} \cdot \mathrm{Al}_{2} \mathrm{O}_{3}$ increased. In the $\mathrm{K}_{2} \mathrm{SO}_{4}-\mathrm{CaO}-\mathrm{Al}_{2} \mathrm{O}_{3}-\mathrm{CaSO}_{4}-\mathrm{SiO}_{2}$ system, to stabilize the formation of $3 \mathrm{CaO} \cdot 3 \mathrm{Al}_{2} \mathrm{O}_{3} \cdot \mathrm{CaSO}_{4}, 2 \mathrm{CaSO}_{4} \cdot \mathrm{K}_{2} \mathrm{SO}_{4}$, and $\beta-2 \mathrm{CaO} \cdot \mathrm{SiO}_{2}$, the molar ratios of $\mathrm{CaO}: \mathrm{Al}_{2} \mathrm{O}_{3}: \mathrm{CaSO}_{4}$ must be kept at 3:3:1 and that of $\mathrm{CaO} / \mathrm{SiO}_{2}$, over 2.0; otherwise, the generated amount of $3 \mathrm{CaO} \cdot 3 \mathrm{Al}_{2} \mathrm{O}_{3} \cdot \mathrm{CaSO}_{4}$ decreased and that of gehlenite $\left(2 \mathrm{CaO} \cdot \mathrm{Al}_{2} \mathrm{O}_{3} \cdot \mathrm{SiO}_{2}\right)$ with no hydration increased quantitatively. Therefore, if all $\mathrm{SO}_{3}(\mathrm{~g})$ generated by the thermal decomposition of alunite reacts with $\mathrm{CaCO}_{3}$ (or $\mathrm{CaO}$, the thermal decomposition product of limestone) to form $\mathrm{CaSO}_{4}$ in an alunite- limestone system, $1 \mathrm{~mol}$ of pure alunite reacts with $6 \mathrm{~mol}$ of limestone to form $1 \mathrm{~mol}$ of $3 \mathrm{CaO} \cdot 3 \mathrm{Al}_{2} \mathrm{O}_{3} \cdot \mathrm{CaSO}_{4}$ and 1 mol of $2 \mathrm{CaSO}_{4} \cdot \mathrm{K}_{2} \mathrm{SO}_{4}$.
\end{abstract}


Keywords: alunite; limestone; calcium sulphoaluminate; calcium langbeinite

\section{Introduction}

Cement has been prepared using alunite [1], and a type of special cement containing calcium aluminate, anhydrite, and potassium sulfate has been prepared using anhydrite formed by the reaction between $\mathrm{SO}_{3}(\mathrm{~g})$ that evolves from alunite and limestone via the following reaction:

$$
\mathrm{K}_{2} \mathrm{SO}_{4} \cdot \mathrm{Al}_{2}\left(\mathrm{SO}_{4}\right)_{3} \cdot 4 \mathrm{Al}(\mathrm{OH})_{3}+\mathrm{mCaCO}_{3} \rightarrow \mathrm{K}_{2} \mathrm{SO}_{4}+3\left(\mathrm{nCaO} \cdot \mathrm{Al}_{2} \mathrm{O}_{3}\right)+3 \mathrm{CaSO}_{4}+\mathrm{mCO}_{2}(\mathrm{~g})+6 \mathrm{H}_{2} \mathrm{O}(\mathrm{g})
$$

Choi et al. [2] synthesized a calcium sulphoaluminate clinker consisting of $3 \mathrm{CaO} \cdot 3 \mathrm{Al}_{2} \mathrm{O}_{3} \cdot \mathrm{CaSO}_{4}$, $\mathrm{CaO}$ and $\mathrm{CaSO}_{4}$ through the sintering for $2 \mathrm{hrs}$ at a temperature of $1,200{ }^{\circ} \mathrm{C}$ of alunite, limestone and an anhydrite mixture at a weight ratio of 1:13:5. Their research results showed that alunite could be used in the preparation of a $3 \mathrm{CaO} \cdot 3 \mathrm{Al}_{2} \mathrm{O}_{3} \cdot \mathrm{CaSO}_{4}$ clinker provided that adequate mixing conditions are provided, despite that the expansion is relatively small compared to that of a clinker synthesized from reagents. However, the exact formation conditions of $3 \mathrm{CaO} \cdot 3 \mathrm{Al}_{2} \mathrm{O}_{3} \cdot \mathrm{CaSO}_{4}$ in the sintering state were not discussed. In addition, Han et al. [3,4] synthesized a clinker containing calcium fluoroaluminate $\left(\mathrm{C}_{11} \mathrm{~A}_{7} \cdot \mathrm{CaF}_{2}\right)$ from domestic alunite and investigated its characteristics in an effort to develop a type of fast-hardening cement.

The authors [5] carried out an investigation of the conditions under which $3 \mathrm{CaO} \cdot 3 \mathrm{Al}_{2} \mathrm{O}_{3} \cdot \mathrm{CaSO}_{4}$ is formed when mixtures of alunite and limestone are sintered. It was concluded that calcium langbeinite $\left(2 \mathrm{CaSO}_{4} \cdot \mathrm{K}_{2} \mathrm{SO}_{4}\right)$ forms from $700{ }^{\circ} \mathrm{C}$ and that calcium sulphoaluminate forms from $800{ }^{\circ} \mathrm{C}$. Both are stable up to $1,300^{\circ} \mathrm{C}$, as shown in the equation below:

$$
\mathrm{K}_{2} \mathrm{SO}_{4} \cdot \mathrm{Al}_{2}\left(\mathrm{SO}_{4}\right)_{3} \cdot 4 \mathrm{Al}(\mathrm{OH})_{3}+6 \mathrm{CaCO}_{3} \rightarrow 4 \mathrm{CaO} \cdot 3 \mathrm{Al}_{2} \mathrm{O}_{3} \cdot \mathrm{SO}_{3}+2 \mathrm{CaSO}_{4} \cdot \mathrm{K}_{2} \mathrm{SO}_{4}+6 \mathrm{H}_{2} \mathrm{O}(\mathrm{g})+6 \mathrm{CO}_{2}(\mathrm{~g})
$$

However, when alunite or limestone is incorporated in $\mathrm{SiO}_{2}$ so as to enable the formation of calcium sulphoaluminate, the molar ratios of $\mathrm{CaO} /$ alunite and $\mathrm{CaO} / \mathrm{SiO}_{2}$ must be kept over 6.0 and 2.0, respectively. A clinker composed of calcium sulphoaluminate and calcium langbeinite was transformed into ettringite $\left(3 \mathrm{CaO} \cdot \mathrm{Al}_{2} \mathrm{O}_{3} \cdot 3 \mathrm{CaSO}_{4} \cdot 32 \mathrm{H}_{2} \mathrm{O}\right)$ in water as calcium langbeinite is transformed into $\mathrm{CaSO}_{4} \cdot 2 \mathrm{H}_{2} \mathrm{O}$ (s) and $\mathrm{K}_{2} \mathrm{SO}_{4}$ (aq) in water.

In the present study, the formation of $3 \mathrm{CaO} \cdot 3 \mathrm{Al}_{2} \mathrm{O}_{3} \cdot \mathrm{CaSO}_{4}$ is identified in a $\mathrm{K}_{2} \mathrm{SO}_{4}-\mathrm{CaO}-\mathrm{Al}_{2} \mathrm{O}_{3}-\mathrm{CaSO}_{4}-\mathrm{SiO}_{2}$ system using reagents of various types in a detailed investigation of the formation conditions of this species through the sintering of a mixture of alunite and limestone.

\section{Experimental}

The reagents listed in Table 1 were used to investigate the reaction products arising from the $\mathrm{K}_{2} \mathrm{SO}_{4}-\mathrm{CaO}-\mathrm{Al}_{2} \mathrm{O}_{3}-\mathrm{CaSO}_{4}-\mathrm{SiO}_{2}$ system. $\mathrm{K}_{2} \mathrm{SO}_{4}$ and $\mathrm{Al}(\mathrm{OH})_{3}$ were used in substitution for the components of alunite; calcium carbonate $\left(\mathrm{CaCO}_{3}\right)$ substituted for limestone, and $\mathrm{CaSO}_{4} \cdot 2 \mathrm{H}_{2} \mathrm{O}$, substituted for anhydrite $\left(\mathrm{CaSO}_{4}\right)$, which is formed by the sintering reaction between alunite and limestone. 
The mixture of reagents were sintered in a programmable electric furnace (Barnstead /Thermolyne F46120 CM High-Temperature Furnace : 240 V, 40 A, 2,500 Watt, 50/60 Hz, 1 Phase) below 1,300 ${ }^{\circ} \mathrm{C}$ in an air atmosphere. The mineral phases of the manufactured clinker were then analyzed by XRD(PW-1700, Philips, 30kV, 25mA, Cu target, Ni filter, at a scanning rate of $2 \% \mathrm{~min}$ ). After the prepared clinker was finely milled with a laboratory ball mill, the mineral phases of the crushed clinker were analyzed by XRD.

Table 1. List of reagents used in this study.

\begin{tabular}{cccl}
\hline Reagents & Chemical formula & Purity & \multicolumn{1}{c}{ Manufacturer } \\
\hline Potassium Sulfate & $\mathrm{K}_{2} \mathrm{SO}_{4}$ & First grade & Ducksan Pharmaceutical Co., Ltd \\
\hline Aluminum Hydroxide & $\mathrm{Al}(\mathrm{OH})_{3}$ & First grade & Shinyo Pure Chemical Co., Ltd \\
\hline Calcium Carbonate & $\mathrm{CaCO}_{3}$ & $\min 98.0 \%$ & Kanto Chemical Co., Inc. \\
\hline Gypsum & $\mathrm{CaSO}_{4} \cdot 2 \mathrm{H}_{2} \mathrm{O}$ & Extra pure & Junsei Chemical Co., Ltd. \\
\hline Silicate Dioxide & $\mathrm{SiO}_{2}$ & Extra pure & Junsei Chemical Co., Ltd. \\
\hline
\end{tabular}

\section{Results and Discussion}

Alunite $\left(\mathrm{K}_{2} \mathrm{SO}_{4} \cdot \mathrm{Al}_{2}\left(\mathrm{SO}_{4}\right)_{3} \cdot 4 \mathrm{Al}(\mathrm{OH})\right)$ is transformed into $\mathrm{KAl}\left(\mathrm{SO}_{4}\right)_{2}$ and $\mathrm{Al}_{2} \mathrm{O}_{3}$ by dehydration at $500 \sim 580{ }^{\circ} \mathrm{C}$ and $\mathrm{KAl}\left(\mathrm{SO}_{4}\right)_{2}, \mathrm{~K}_{2} \mathrm{SO}_{4}$ and $\mathrm{Al}_{2} \mathrm{O}_{3}$ by desulphurization at $700 \sim 780{ }^{\circ} \mathrm{C}$ via the reaction of $\mathrm{K}_{2} \mathrm{SO}_{4} \cdot \mathrm{Al}_{2}\left(\mathrm{SO}_{4}\right)_{3} \cdot 4 \mathrm{Al}(\mathrm{OH})_{3} \rightarrow \mathrm{K}_{2} \mathrm{SO}_{4}+2 \mathrm{Al}_{2} \mathrm{O}_{3}+3 \mathrm{SO}_{3}(\mathrm{~g})+6 \mathrm{H}_{2} \mathrm{O}(\mathrm{g})$, regardless of the partial pressure of $\mathrm{CO}_{2}(\mathrm{~g})$. However, limestone decomposes from $650{ }^{\circ} \mathrm{C}$ in air and from $900{ }^{\circ} \mathrm{C}$ in a $\mathrm{CO}_{2}(\mathrm{~g})$ saturated atmosphere [6].

When the mixture of alunite and limestone is sintered in air and in $\mathrm{CO}_{2}(\mathrm{~g})$ saturated atmosphere, the rate of formation of anhydrite is relatively low, at $76.0 \%$ and $67.0 \%$, respectively, at a $\mathrm{CaCO}_{3} /$ alunite stoichiometric molar ratio of 3 . However, the rate of formation increases as the molar ratio of $\mathrm{CaCO}_{3}$ /alunite (particle size, $37 \sim 44 \mu \mathrm{m}$ ) exceeds 6 , showing rates of more than $99.0 \%$ and $95.0 \%$ in air and in a $\mathrm{CO}_{2}(\mathrm{~g})$ saturated atmosphere, respectively [7].

As shown in the results of aforementioned experiment, if alunite and limestone are mixed and sintered in air, most of the generated $\mathrm{SO}_{3}$ reacts with limestone to form anhydrite $\left(\mathrm{CaSO}_{4}\right)$. Additionally, ignoring impurities such as $\mathrm{Fe}_{2} \mathrm{O}_{3}, \mathrm{TiO}_{2}$, and $\mathrm{P}_{2} \mathrm{O}_{5}$ included in the alunite, because alunite ore is composed of alunite, quartz $\left(\mathrm{SiO}_{2}\right)$, and the aluminum silicate minerals of kaolinite, dickite, and pyrophyllite, the alunite and limestone mixture can be said to have five components, as does $\mathrm{K}_{2} \mathrm{SO}_{4}-\mathrm{CaO}-\mathrm{Al}_{2} \mathrm{O}_{3}-\mathrm{CaSO}_{4}-\mathrm{SiO}_{2}$.

If $1 \mathrm{~mol}$ if pure alunite is heated to temperatures that exceed $800{ }^{\circ} \mathrm{C}$, it is pyrolyzed as $\mathrm{K}_{2} \mathrm{SO}_{4} \cdot \mathrm{Al}_{2}\left(\mathrm{SO}_{4}\right)_{3} \cdot 4 \mathrm{Al}(\mathrm{OH})_{3} \rightarrow \mathrm{K}_{2} \mathrm{SO}_{4}+3 \mathrm{Al}_{2} \mathrm{O}_{3}+3 \mathrm{SO}_{3}+6 \mathrm{H}_{2} \mathrm{O}$. Therefore, to formulate $\mathrm{SO}_{3}(\mathrm{~g})$ of 3 mol into anhydrite, $3 \mathrm{~mol}$ of $\mathrm{CaCO}_{3}$ is required, and to change $3 \mathrm{~mol}$ of $\mathrm{Al}_{2} \mathrm{O}_{3}$ into $3 \mathrm{CaO} \cdot 3 \mathrm{Al}_{2} \mathrm{O}_{3} \cdot \mathrm{CaSO}_{4}$, 3 additional mol of $\mathrm{CaCO}_{3}$ and $1 \mathrm{~mol}$ of $\mathrm{CaSO}_{4}$ will be needed. Therefore, to change all of the $\mathrm{Al}_{2} \mathrm{O}_{3}$ in alunite into $3 \mathrm{CaO} \cdot 3 \mathrm{Al}_{2} \mathrm{O}_{3} \cdot \mathrm{CaSO}_{4}$, and to generate $\mathrm{SO}_{3}(\mathrm{~g})$ by the thermal decomposition of alunite into anhydrite, theoretically, pure alunite and limestone should be mixed at a molar rate of 1:6. This mixture will be composed of five component systems as in $\mathrm{K}_{2} \mathrm{SO}_{4}-\mathrm{CaO}-\mathrm{Al}_{2} \mathrm{O}_{3}-\mathrm{CaSO}_{4}$. 
The present study aims to determine the mineral phases of a clinker generated in the $\mathrm{K}_{2} \mathrm{SO}_{4}-\mathrm{CaO}-\mathrm{Al}_{2} \mathrm{O}_{3}-\mathrm{CaSO}_{4}$ and the $\mathrm{K}_{2} \mathrm{SO}_{4}-\mathrm{CaO}-\mathrm{Al}_{2} \mathrm{O}_{3}-\mathrm{CaSO}_{4}-\mathrm{SiO}_{2}$ systems, using several types of reagents, including $\mathrm{K}_{2} \mathrm{SO}_{4}, \mathrm{Al}(\mathrm{OH})_{3}, \mathrm{SiO}_{2}, \mathrm{CaSO}_{4} \cdot 2 \mathrm{H}_{2} \mathrm{O}$, and $\mathrm{CaCO}_{3}$.

Figure 1 shows $\mathrm{X}$-ray diffraction patterns of the materials generated, when a compound consisting of $\mathrm{K}_{2} \mathrm{SO}_{4}-3 \mathrm{CaO}-3 \mathrm{Al}_{2} \mathrm{O}_{3}-3 \mathrm{CaSO}_{4}$ was sintered at $1,100{ }^{\circ} \mathrm{C}, 1,200{ }^{\circ} \mathrm{C}$, and $1,300{ }^{\circ} \mathrm{C}$, respectively, for 2 hours. As shown in this figure, $3 \mathrm{CaO} \cdot 3 \mathrm{Al}_{2} \mathrm{O}_{3} \cdot \mathrm{CaSO}_{4}$ and $2 \mathrm{CaSO}_{4} \cdot \mathrm{K}_{2} \mathrm{SO}_{4}$ is formed, but $\mathrm{CaSO}_{4}$ does not react and remains at $1,100{ }^{\circ} \mathrm{C}$. Meanwhile, at temperatures in excess of $1,200{ }^{\circ} \mathrm{C} 3 \mathrm{CaO} \cdot 3 \mathrm{Al}_{2} \mathrm{O}_{3} \cdot \mathrm{CaSO}_{4}$ and $2 \mathrm{CaSO}_{4} \cdot \mathrm{K}_{2} \mathrm{SO}_{4}$ were mainly generated. Accordingly, $1 \mathrm{~mol}$ of pure alunite reacts with 6 mol of limestone to form $1 \mathrm{~mol}$ of $3 \mathrm{CaO} \cdot 3 \mathrm{Al}_{2} \mathrm{O}_{3} \cdot \mathrm{CaSO}_{4}$ and $1 \mathrm{~mol}$ of $2 \mathrm{CaSO}_{4} \cdot \mathrm{K}_{2} \mathrm{SO}_{4}$ as follows; $\mathrm{K}_{2} \mathrm{SO}_{4} \cdot \mathrm{Al}_{2}\left(\mathrm{SO}_{4}\right)_{3} \cdot 4 \mathrm{Al}(\mathrm{OH})_{3}+6 \mathrm{CaCO}_{3} \rightarrow 2 \mathrm{CaSO}_{4} \cdot \mathrm{K}_{2} \mathrm{SO}_{4}+3 \mathrm{CaO} \cdot 3 \mathrm{Al}_{2} \mathrm{O}_{3} \cdot \mathrm{CaSO}_{4}+6 \mathrm{H}_{2} \mathrm{O}(\mathrm{g})+$ $6 \mathrm{CO}_{2}(\mathrm{~g})$.

Figure 1. X-ray diffraction patterns of sintered products of mixtures of $\mathrm{K}_{2} \mathrm{SO}_{4}-3 \mathrm{CaO}-3 \mathrm{Al}_{2} \mathrm{O}_{3}-3 \mathrm{CaSO}_{4}$ at various temperatures in air.

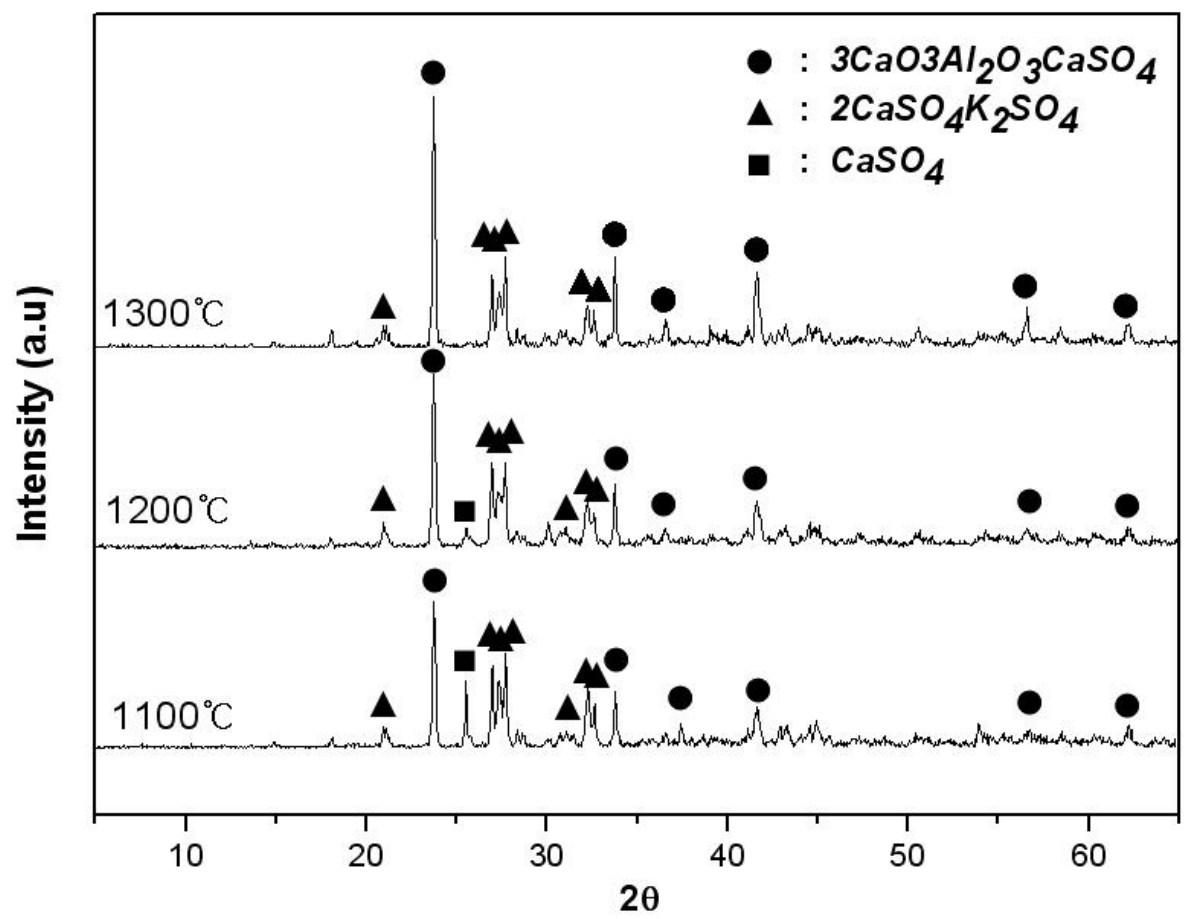

Figure 2 displays the materials generated from $\mathrm{K}_{2} \mathrm{SO}_{4}-\mathrm{nCaO}-3 \mathrm{Al}_{2} \mathrm{O}_{3}-3 \mathrm{CaSO}_{4}$ with various amounts of $\mathrm{CaO}$ sintered at $1,200{ }^{\circ} \mathrm{C}$ for two hours, as determined via an XRD analysis. 
Figure 2. X-ray diffraction patterns of sintered products of mixtures of $\mathrm{K}_{2} \mathrm{SO}_{4}-\mathrm{nCaO}-3 \mathrm{Al}_{2} \mathrm{O}_{3}-3 \mathrm{CaSO}_{4}$ with various amounts of $\mathrm{CaO}$ in air (sintering temp.: $1,200{ }^{\circ} \mathrm{C}$, sintering time: $2 \mathrm{hrs}$ ).

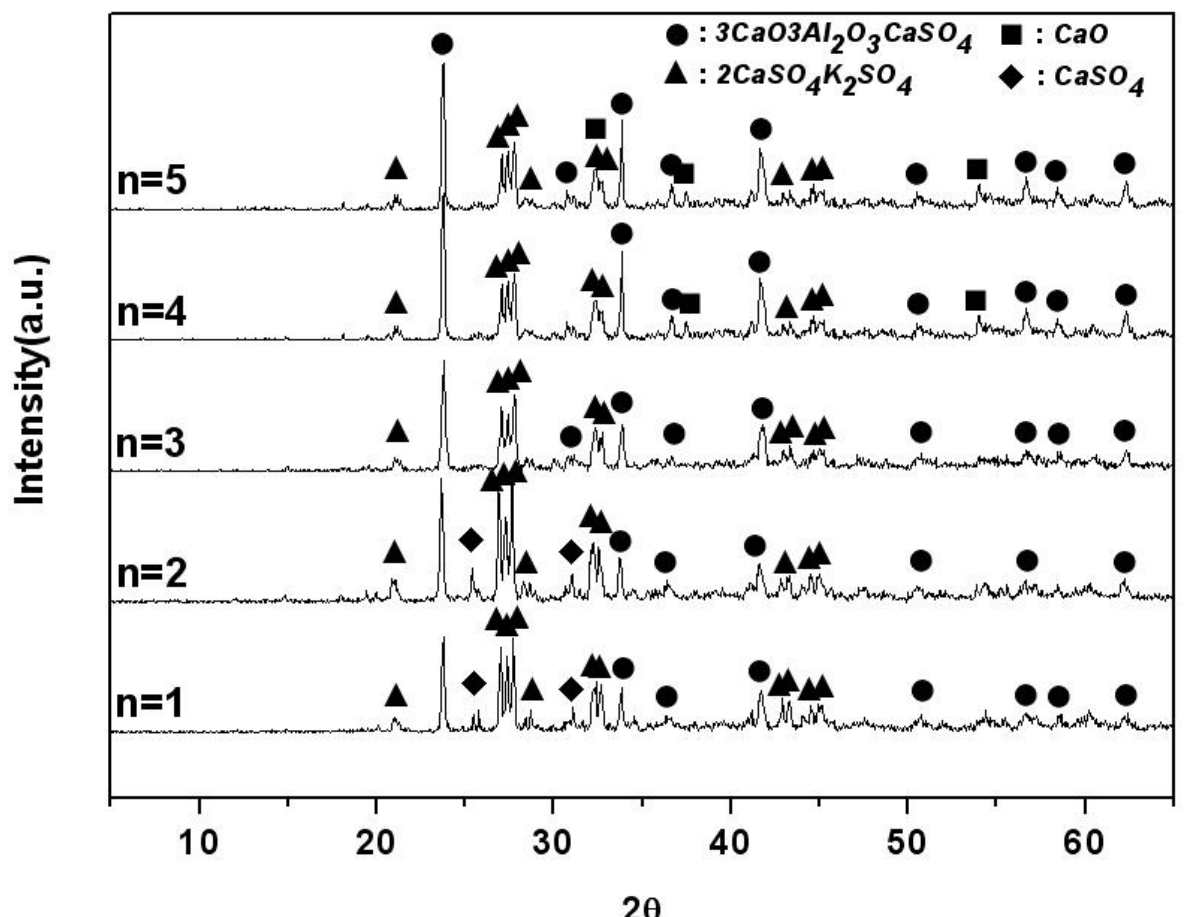

When it $\mathrm{CaO}$ is included in at an amount of $3 \mathrm{~mol}, 3 \mathrm{CaO} \cdot 3 \mathrm{Al}_{2} \mathrm{O}_{3} \cdot \mathrm{CaSO}_{4}$ and $2 \mathrm{CaSO}_{4} \cdot \mathrm{K}_{2} \mathrm{SO}_{4}$ are mainly generated. However, it was found that as the amount of $\mathrm{CaO}$ is increased from $3 \mathrm{~mol}$ to $5 \mathrm{~mol}$, $\mathrm{CaO}$ does not participate in the formation reaction of $3 \mathrm{CaO} \cdot 3 \mathrm{Al}_{2} \mathrm{O}_{3} \cdot \mathrm{CaSO}_{4}$. Thus, it can be said that $3 \mathrm{CaO} \cdot 3 \mathrm{Al}_{2} \mathrm{O}_{3} \cdot \mathrm{CaSO}_{4}$ and $2 \mathrm{CaSO}_{4} \cdot \mathrm{K}_{2} \mathrm{SO}_{4}$ are generated stably when $\mathrm{CaO}$ is $3 \mathrm{~mol}$ in the $\mathrm{K}_{2} \mathrm{SO}_{4}-\mathrm{nCaO}-3 \mathrm{Al}_{2} \mathrm{O}_{3}-3 \mathrm{CaSO}_{4}$ system.

According to Fukuda [8] $3 \mathrm{CaO} \cdot 3 \mathrm{Al}_{2} \mathrm{O}_{3} \cdot \mathrm{CaSO}_{4}$ is the only compound in the $\mathrm{CaO}-\mathrm{Al}_{2} \mathrm{O}_{3}-\mathrm{SO}_{3}$ system. This line of research was started in 1962 by Halstead, et al. [9] with $\mathrm{Ca}^{2+}$ and $\mathrm{SO}_{4}{ }^{2-}$ ions in a three-dimensional crystal structure sharing the angular point of a $\mathrm{AlO}_{4}$ tetrahedron; an $\mathrm{Al}^{3+}$ ion is coordinated with four $\mathrm{O}^{2-}$ ions, a $\mathrm{Ca}^{2+}$ ion is surrounded asymmetrically by $\mathrm{O}^{2-}$ ions, and an isolated $\mathrm{SO}_{4}{ }^{2-}$ ion is characterized by its ability to readily react with water. Kondo [10] discovered that these ions become hardened in water. In general, they are produced by re-sintering after producing $3 \mathrm{CaO} \cdot \mathrm{Al}_{2} \mathrm{O}_{3}$ and regulating the mixture ratio of $3 \mathrm{CaO} \cdot \mathrm{Al}_{2} \mathrm{O}_{3}, \mathrm{CaSO}_{4} \cdot 2 \mathrm{H}_{2} \mathrm{O}$ and $\mathrm{Ca}(\mathrm{OH})_{2}$ and by sintering a mixture of $\mathrm{CaCO}_{3}, \mathrm{Al}_{2} \mathrm{O}_{3}$, and $\mathrm{CaSO}_{4} \cdot 2 \mathrm{H}_{2} \mathrm{O}$.

$2 \mathrm{CaSO}_{4} \cdot \mathrm{K}_{2} \mathrm{SO}_{4}$ is easily generated in the $\mathrm{CaO}-\mathrm{Al}_{2} \mathrm{O}_{3}-\mathrm{SiO}_{2}-\mathrm{Fe}_{2} \mathrm{O}_{3}-\mathrm{MgO}-\mathrm{CaSO}_{4}-\mathrm{K}_{2} \mathrm{SO}_{4}$ system and has a considerable influence on the condensation time and the hardening characteristics of cements. Known as a water-soluble alkali, as $2 \mathrm{CaSO}_{4} \cdot \mathrm{K}_{2} \mathrm{SO}_{4}$ can be easily separated from the liquid state of a clinker oxide and is said to become $\mathrm{K}_{2} \mathrm{SO}_{4} \cdot \mathrm{CaSO}_{4} \cdot \mathrm{H}_{2} \mathrm{O}$ (syngenite) and $\mathrm{CaSO}_{4} \cdot 2 \mathrm{H}_{2} \mathrm{O}$ upon exposure to water [11].

Figure 3 shows the materials generated from the $\mathrm{K}_{2} \mathrm{SO}_{4}-3 \mathrm{CaO}-3 \mathrm{Al}_{2} \mathrm{O}_{3}-\mathrm{nCaSO} \mathrm{S}_{4}$ system sintered at $1,200{ }^{\circ} \mathrm{C}$ for two hours with varying amounts of anhydrite, as determined via an XRD analysis. 
Figure 3. X-ray diffraction patterns of sintered products of mixtures of $\mathrm{K}_{2} \mathrm{SO}_{4}-3 \mathrm{CaO}-3 \mathrm{Al}_{2} \mathrm{O}_{3}$-nCaSO 4 with various amounts of $\mathrm{CaSO}_{4}$ in air (sintering temp.: $1,200{ }^{\circ} \mathrm{C}$, sintering time: $2 \mathrm{hrs}$ ).

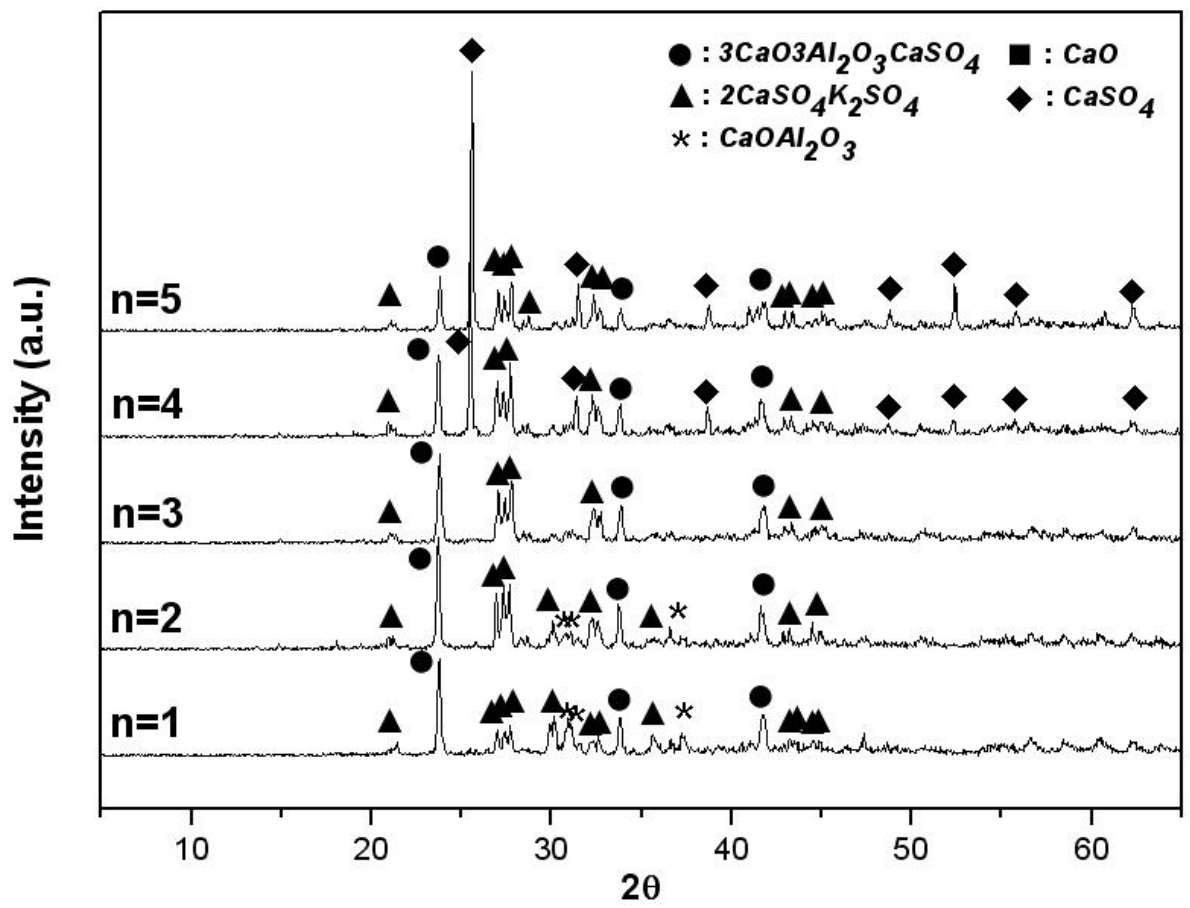

As shown in this figure, when anhydrite is included in an amount of $3 \mathrm{~mol}, 3 \mathrm{CaO} \cdot 3 \mathrm{Al}_{2} \mathrm{O}_{3} \cdot \mathrm{CaSO}_{4}$ and $2 \mathrm{CaSO}_{4} \cdot \mathrm{K}_{2} \mathrm{SO}_{4}$ are generated. However, as the amount of anhydrite is decreased from $3 \mathrm{~mol}$ to $1 \mathrm{~mol}$, it was observed that the $\mathrm{K}_{2} \mathrm{SO}_{4}$ that did not react with $\mathrm{CaO} \cdot \mathrm{Al}_{2} \mathrm{O}_{3}$ remained. As the amount of anhydrite is increased from $3 \mathrm{~mol}$ to $5 \mathrm{~mol}$, only the diffraction strength of the $\mathrm{CaSO}_{4}$ that does not react increases. Thus, it can be said that an amount of $\mathrm{CaSO}_{4}$ in excess of the stoichiometric molar ratio is necessary to generate $3 \mathrm{CaO} \cdot 3 \mathrm{Al}_{2} \mathrm{O}_{3} \cdot \mathrm{CaSO}_{4}$ stably.

As noted above, $3 \mathrm{CaO} \cdot 3 \mathrm{Al}_{2} \mathrm{O}_{3} \cdot \mathrm{CaSO}_{4}$ and $2 \mathrm{CaSO}_{4} \cdot \mathrm{K}_{2} \mathrm{SO}_{4}$ were mainly generated in the $\mathrm{K}_{2} \mathrm{SO}_{4}-3 \mathrm{CaO}-3 \mathrm{Al}_{2} \mathrm{O}_{3}-3 \mathrm{CaSO}_{4}$ system. However, because alunite from nature has impurities of $\mathrm{SiO}_{2}$ and aluminum silicate minerals such as kaolinite, dickite, and pyrophyllite, the alunite and limestone mixture is believed to be comprised of $\mathrm{K}_{2} \mathrm{SO}_{4}-\mathrm{CaO}-\mathrm{Al}_{2} \mathrm{O}_{3}-\mathrm{CaSO}_{4}-\mathrm{SiO}_{2}$ system to which $\mathrm{SiO}_{2}$ is added.

Figures 4 and 5 show, by $\mathrm{XRD}$ analysis, the materials generated from the $\mathrm{K}_{2} \mathrm{SO}_{4}-3 \mathrm{CaO}-3 \mathrm{Al}_{2} \mathrm{O}_{3}-3 \mathrm{CaSO}_{4}-\mathrm{nSiO}_{2}$ system and the $\mathrm{K}_{2} \mathrm{SO}_{4}-(3+\mathrm{m}) \mathrm{CaO}-3 \mathrm{Al}_{2} \mathrm{O}_{3}-3 \mathrm{CaSO}_{4}-\mathrm{nSiO}_{2}$ system, respectively, sintered at $1,200{ }^{\circ} \mathrm{C}$ for 2 hours, with various amounts of $\mathrm{CaO}(3+\mathrm{m}:$ mol number $)$ and $\mathrm{SiO}_{2}$ (n: mol number). In Figure 4, when there is no $\mathrm{SiO}_{2}$ in the mixture, the result is identical to that obtained when $3 \mathrm{~mol}$ of $\mathrm{CaO}$ is used (Figure 2). It is expected that $3 \mathrm{CaO} \cdot 3 \mathrm{Al}_{2} \mathrm{O}_{3} \cdot \mathrm{CaSO}_{4}$ and $2 \mathrm{CaSO}_{4} \cdot \mathrm{K}_{2} \mathrm{SO}_{4}$ will be generated. However, as the amount of $\mathrm{SiO}_{2}$ is increased from $1 \mathrm{~mol}$ to $5 \mathrm{~mol}$, the amount of $3 \mathrm{CaO} \cdot 3 \mathrm{Al}_{2} \mathrm{O}_{3} \cdot \mathrm{CaSO}_{4}$ generated is reduced, because gehlenite $\left(2 \mathrm{CaO} \cdot \mathrm{Al}_{2} \mathrm{O}_{3} \cdot \mathrm{SiO}_{2}\right)$ and wollastonite $\left(\alpha-\mathrm{CaO} \cdot \mathrm{SiO}_{2}\right)$, which do not react with water, are generated. In addition, as shown in Figure 5, when the mol rate of $\mathrm{CaO} /$ alunite is less than 6 (m less than 3 ), and that of $\mathrm{CaO} / \mathrm{SiO}_{2}$ is less than 2, the synthetic clinker contained $2 \mathrm{CaO} \cdot \mathrm{Al}_{2} \mathrm{O}_{3} \cdot \mathrm{SiO}_{2}$ and $\mathrm{CaSO}_{4}$; these compounds do not participate in the formation reaction of $3 \mathrm{CaO} \cdot 3 \mathrm{Al}_{2} \mathrm{O}_{3} \cdot \mathrm{CaSO}_{4}$ because $3 \mathrm{CaO} \cdot 3 \mathrm{Al}_{2} \mathrm{O}_{3} \cdot \mathrm{CaSO}_{4}$ is the only compound in the $\mathrm{CaO}-\mathrm{Al}_{2} \mathrm{O}_{3}-\mathrm{SO}_{3}$ system as noted above[8] and $\mathrm{CaO}$ and $\mathrm{Al}_{2} \mathrm{O}_{3}$ participate 
preferentially in the formation reaction of $2 \mathrm{CaO} \cdot \mathrm{Al}_{2} \mathrm{O}_{3} \cdot \mathrm{SiO}_{2}$. Accordingly, if all $\mathrm{SO}_{3}(\mathrm{~g})$ generated by thermal decomposition of alunite reacts with $\mathrm{CaCO}_{3}$ (or $\mathrm{CaO}$, the thermal decomposition product of limestone) to form $\mathrm{CaSO}_{4}$ in the alunite-limestone system, when the molar ratios of $\mathrm{CaO} /$ alunite exceed 6 and that of $\mathrm{CaO} / \mathrm{SiO}_{2}$ exceeds $2,3 \mathrm{CaO} \cdot 3 \mathrm{Al}_{2} \mathrm{O}_{3} \cdot \mathrm{CaSO}_{4}, 2 \mathrm{CaSO}_{4} \cdot \mathrm{K}_{2} \mathrm{SO}_{4}$ and $\beta-2 \mathrm{CaO} \cdot \mathrm{SiO}_{2}$ are generated stably.

Figure 4. X-ray diffraction patterns of sintered products of mixtures of $\mathrm{K}_{2} \mathrm{SO}_{4}-3 \mathrm{CaO}-3 \mathrm{Al}_{2} \mathrm{O}_{3}-3 \mathrm{CaSO}_{4}-\mathrm{nSiO}_{2}$ with various amounts of $\mathrm{SiO}_{2}$ in air (sintering temp.: $1,200{ }^{\circ} \mathrm{C}$, sintering time: $2 \mathrm{hrs}$ ).

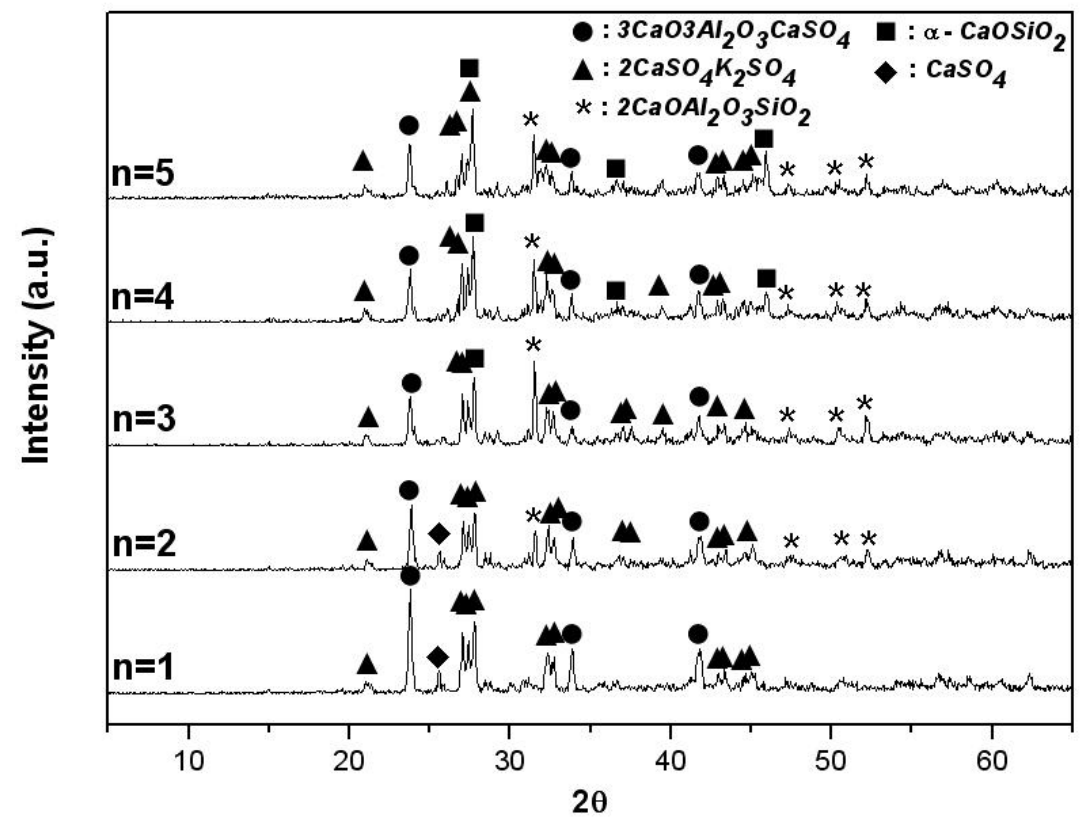

Figure 5. X-ray diffraction patterns of sintered products of mixtures of $\mathrm{K}_{2} \mathrm{SO}_{4}$ $-[(3+\mathrm{m}) \mathrm{CaO}]-3 \mathrm{Al}_{2} \mathrm{O}_{3}-3 \mathrm{CaSO}_{4}-\mathrm{nSiO}_{2}$ with various amounts of $\mathrm{CaO}$ and $\mathrm{SiO}_{2}$ in air (sintering temp.: $1,200{ }^{\circ} \mathrm{C}$, sintering time: $2 \mathrm{hrs}$ ).

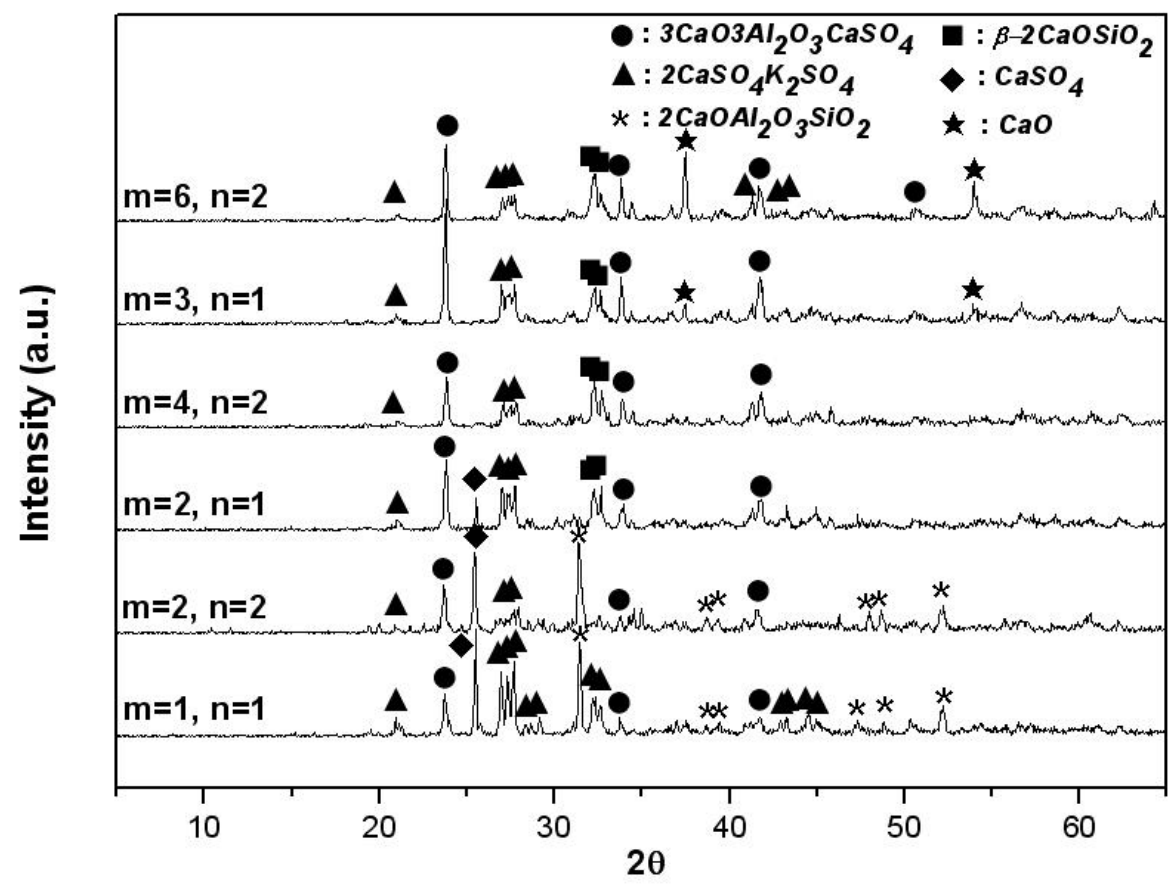




\section{Conclusions}

This study investigated the formation characteristics of calcium sulphoaluminate $\left(4 \mathrm{CaO} \cdot 3 \mathrm{Al}_{2} \mathrm{O}_{3} \cdot \mathrm{SO}_{3}\right)$ in a $\mathrm{K}_{2} \mathrm{SO}_{4}-\mathrm{CaO}-\mathrm{Al}_{2} \mathrm{O}_{3}-\mathrm{CaSO}_{4}-\mathrm{SiO}_{2}$ system using reagents of various types in an effort to identify the formation conditions of $3 \mathrm{CaO} \cdot 3 \mathrm{Al}_{2} \mathrm{O}_{3} \cdot \mathrm{CaSO}_{4}$ by the sintering of a mixture of alunite and limestone. In experiments with reagents for the mineral phases generated from the compound system (the $\mathrm{K}_{2} \mathrm{SO}_{4}-\mathrm{CaO}-\mathrm{Al}_{2} \mathrm{O}_{3}-\mathrm{CaSO}_{4}-\mathrm{SiO}_{2}$ system), if all $\mathrm{SO}_{3}(\mathrm{~g})$ from alunite reacts with limestone to form anhydrite, it was found that $1 \mathrm{~mol}$ of pure alunite reacts with $6 \mathrm{~mol}$ of limestone to form $1 \mathrm{~mol}$ of $3 \mathrm{CaO} \cdot 3 \mathrm{Al}_{2} \mathrm{O}_{3} \cdot \mathrm{CaSO}_{4}$ and $1 \mathrm{~mol}$ of $2 \mathrm{CaSO}_{4} \cdot \mathrm{K}_{2} \mathrm{SO}_{4}$, as of $3 \mathrm{CaO} \cdot 3 \mathrm{Al}_{2} \mathrm{O}_{3} \cdot \mathrm{CaSO}_{4}$ and $2 \mathrm{CaSO}_{4} \cdot \mathrm{K}_{2} \mathrm{SO}_{4}$ are generated stably at a component ratio of $\mathrm{K}_{2} \mathrm{SO}_{4}-3 \mathrm{CaO}-3 \mathrm{Al}_{2} \mathrm{O}_{3}-3 \mathrm{CaSO}_{4}$. Over-mixing of $\mathrm{CaO}$ and $\mathrm{CaSO}_{4}$ has a slight effect on the generation of $3 \mathrm{CaO} \cdot 3 \mathrm{Al}_{2} \mathrm{O}_{3} \cdot \mathrm{CaSO}_{4}$. However, it is thought that under-mixing will have a substantial effect on the mineral phase of the clinker and on the amount of $3 \mathrm{CaO} \cdot 3 \mathrm{Al}_{2} \mathrm{O}_{3} \cdot \mathrm{CaSO}_{4}$ that is generated. Moreover, if the impurities of $\mathrm{SiO}_{2}$ are incorporated in the alunite and limestone, the molar ratio of $\mathrm{CaO} /$ alunite must exceed 6 and that of $\mathrm{CaO} / \mathrm{SiO}_{2}$ must exceed 2 in order to ensure the stable formation of calcium sulphoaluminate, calcium langbeinite, and the $\beta-2 \mathrm{CaO} \cdot \mathrm{SiO}_{2}$ phases. Otherwise, the amount of gehlenite $\left(2 \mathrm{CaO} \cdot \mathrm{Al}_{2} \mathrm{O}_{3} \cdot \mathrm{SiO}_{2}\right)$, which does not react with water, may be increased.

\section{References}

1. Sanada, Y.; Saito, C.; Miyanawa, K. Studies on preparation of speacial high aluminous cement from alunite(I). J. Korean Ceram. Soc. 1949, 57, 32-34.

2. Choi, S.H.; Han, S.M. Studies on hydration expansibility of calcium sulfoaluminate clinkers. $J$. Korean Ceram. Soc. 1971, 8, 98-103.

3. Han, K.S. Studies on alumina cement from alunite(I) (synthesis of monocalcium aluminate). $J$. Korean Ceram. Soc. 1978, 15, 199.

4. Han, K.S.; Choi, S.H.; Song, T.-U. Studies on alumina cement from alunite(II) (physical properties of alumina cement). J. Korean Ceram. Soc. 1979, 16, 164-168.

5. Kim, H.S.; Ahn, J.W.; Hyun, J.Y.; Cho, D.S. Synthesis of calcium sulfoaluminate clinker using alunite. Mater. Sci. Forum 2003, 439, 106-114.

6. Kim, H.S.; Cho, D.S. A study on the thermal decomposition of alunite. J. Korean Inst. Resour. Recyc. 1998, 7, 33.

7. Kim, H.S.; Ahn, J.W.; Kim, H.; Shin, G.H.; Cho, D.S. Synthesis of anhydrite in the mixtures of alunite and limestone by roasting. J. Korean Cryst. Growth Cryst. Technol. 2001, 11, 190.

8. Fukuda, N. Fundermental studies on the expansive cement. In Proceedings of the 5th International Symposium on the Chemistry of Cement, Tokyo, Japan, May 1968; p. 311.

9. Halstead, P.E.; Moor, A.E. The composition and crystallography of an anhydrous calcium aluminosulphate accuing in expanding cement. J. Appl. Chem. 1962, 12, 413-417.

10. Kondo, $\mathrm{R}$. The synthesis and crystallography of a group of new compounds belonging to the hauyne type structure. J. Ceram. Soc. Jpn. 1965, 73, 1-8. 
11. Kapralik, I.; Hanic, F.; Havlica, J.; Ambruz, V. Sub-solidus phase ralations in the system $\mathrm{CaO}-\mathrm{Al}_{2} \mathrm{O}_{3}-\mathrm{SiO}_{2}-\mathrm{Fe}_{2} \mathrm{O}_{3}-\mathrm{MgO}-\mathrm{CaSO}_{4}-\mathrm{K}_{2} \mathrm{SO}_{4}$ at $950{ }^{\circ} \mathrm{C}$ in air referred to sulphoaluminate cement clinker. Trans. J. Brit. Ceram. Soc. 1986, 85, 107-110.

(C) 2009 by the authors; licensee Molecular Diversity Preservation International, Basel, Switzerland. This article is an open-access article distributed under the terms and conditions of the Creative Commons Attribution license (http://creativecommons.org/licenses/by/3.0/). 